Editorial

\title{
Mis-conceived and Mis-implemented Academic Assessment Rules Underlie the Scourge of Predatory Journals and Conferences
}

\author{
S C LAKHOTIA* \\ Cytogenetics Laboratory, Department of Zoology, Banaras Hindu University, Varanasi 221 005, India
}

Most of the academics in India (and elsewhere) would be annoyingly familiar with daily emails in their inboxes inviting submission of research articles to a journal for rapid (or even ultra-rapid) publication for a fee, or inviting participation in some conference. There are several common features of such mails inviting articles for publication. Most of the invites have only an email and/or a web-address, a geographical address being infrequent, and if the journal happens to be in a discipline with which the recipient is familiar, the recipient would be 'embarrassed' that he/she knows neither the editor nor the journal, which often claims high 'impact factor'. These mails promise rapid publication (ultra-rapid on demand, if there is an 'emergency') if the publication/open access charge is paid in advance. Another common feature of such invitations is that most of them may not bear any relationship with the recipient's expertise. The invitee may like to feel elated at being considered 'knowledgeable' in completely unrelated fields to deserve an invitation. Such invitations are indeed from editors/managers of predatory journals and predatory conferences who cast their net wide like the fisherman who wants to catch as many fishes as in the area as possible. The prey, who is in dire need to have some publication to his/her 'credit', gets attracted by the invitation and contributes to the coffers of these managers. Interestingly, however, the relation between the predator and the prey in the case of such publications or conferences is unlike the typical "predator gains and prey loses" relationship. In this game, both the predator and the prey turn out to be 'beneficiaries'. The 'prey' (author), who needs some evidence of 'academic' activity to prove his/her eligibility for moving ahead in the professional ladder, secures the required 'credit' in exchange for the money that the predatory journal manager or conference organizer earns in the deal. Such mutually beneficial arrangement has led to such journals and conferences becoming a rapidly expanding 'business'. What suffers in such transactions is the academic quality (Lakhotia, 2015). Unfortunately, India has a dubious distinction of standing fairly high in the list of countries which publish predatory journals or where such bogus conferences are supposedly held.

Many factors have contributed to the origin and evolution of predatory journals. The universal use of internet and soft copy documents (pdf files) and the availability of public domain software for journal management that are amenable to individualization for online submission of manuscripts and subsequent online publication have certainly made the lives of authors, editors, reviewers, readers and, of course, the journal managers much easier. The commercial publishing houses actively promoted a change from 'reader pays' to 'author pays' model of research publications and this has been, unfortunately, widely accepted by authors and funding agencies. The already in vogue practice of various kinds of charges (page, colour, open-access and/or processing charges etc) paid by authors to get their works published, came handy and attractive to the managers of predatory journals (Lakhotia, 2017). While all these prepared the ground, the major catalyst or inducer for the spurt in mushrooming of such journals was the demand created by increasing emphasis on the number of research publications as an important determinant of the academic performance of a faculty/scientist being considered for appointment or promotion. With a view to improve the quality of research in the large number of colleges and universities in India, the University

*Author for Correspondence: E-mail:lakhotia@bhu.ac.in 
Grants Commission (UGC) came out with guidelines, converted into rules, for maintaining minimal academic standards. One component of this package of rules requires a research scholar to publish a certain minimum number of research papers prior to submission of the doctoral thesis and likewise, any applicant for faculty positions is required to have published a certain minimal number of articles to be eligible for consideration. While such conditions look positive, the ground realities in majority of colleges and universities in the country are far below the minimal infrastructure required for any kind of research. Since most of them are not even capable of conducting the laboratory work associated with the course being taught, expecting quality research at such places is a wishful thinking. Thus without preparing the ground, prospective and existing faculty members were mandated to 'produce' research papers, without any operational definition of quality. The gross mismatch between the existing infrastructure and competence on one hand, and what is demanded of the applicants on the other, proved to be an extremely fertile ground for the mushrooming of predatory journals, especially when all that mattered was the number of papers published by an individual with little consideration for quality. Given the mediocrity existing in most of the country's universities and colleges, little concern was expressed initially about the malignant growth of predatory journals and meaningless 'research publications' that flooded their pages. All the concerned parties seemed to be happy: the administrators were appreciated by the beneficiaries for being 'sympathetic' to the faculty's aspirations, the concerned faculty secured the required points and thus got appointed/promoted while the managers/editors of such journals made good money. As the voices of concern at this depressing scenario gathered some force and became audible above the background noise, an effort was initiated to formally identify predatory journals so that publications in those journals would not be considered. However, such formal recognition of a journal as a 'predatory journal' was never an easy or even a possible task. Yet, when such an effort was initiated, it was very swiftly outpaced by the predatory journal managers who appropriately modified their websites etc to match with 'good' journals. Consequently, the so-called 'list of journals approved by UGC' has become all inclusive! Obviously, such a list entails further erosion of academic standards.

The situation is really vexed. Given the mediocrity existing at all levels in the various universities and colleges (as is unfortunately also generally true elsewhere), it is unlikely that the prevailing system would on its own become truly conscious of quality. At the same time, imposition of rules without first preparing the ground, like what has been done by the UGC, cannot do any good but would create more harm, as already seen. A general impression is that the quality of faculty hired in various universities and colleges during the past 6-7 years, since enforcement of the UGC rules for maintenance of minimal standards, is no better than what it was before; it may in fact be a little worse on average.

One would not question the good intentions of the UGC while introducing these measures for maintaining minimal academic quality. However, in the absence of a minimally required infrastructure and any quality check parameters, and with these rules being implemented by the system which itself often falls short of the desired level of quality, these measures have actually inflicted more damage than improving the quality of faculty or of the education being imparted. Given the present scenario, it may actually be better to let things float freely so that at least some good ones will also swim ahead and get appointed as faculty.

What the country needs is a very serious overhaul of the university and college system and its management. This can happen only with a well thought-out and discussed policy and with a long-term resolve for its implementation. Formulation of such a policy would minimally require that the UGC and all other regulatory and granting agencies and governmental ministries seriously collaborate and agree to take an integrative approach to address the real issues rather than each one taking un-coordinated independent knee-jerk steps. Such ostensibly 'forwardlooking' steps that are periodically announced by different agencies in isolation only produce ad-hoc solutions with possibility of some very short-term relief but finally inflicting a long-term negative impact and lasting damage. An example of such knee-jerk reaction is provided by the recent media report that the undergraduate college teachers would not be required to 
engage in research to be eligible for promotion. Hopefully, this would reduce, to some extent at least, the scourge of predatory journals and conferences. However, what about the lauded role of under-graduate research as a catalyst for generating future competent researchers? The current guidelines issued by the UGC require every under-graduate student to undertake a research project. Who would guide them and how, remains a big question mark if their teachers themselves are not required to be involved in some research? This situation is like accepting that it is not possible to create an appropriate environment in colleges and universities for improving their academic performance and, therefore, throw the baby with the bathtub! The policy makers and administrators, who rightfully can boast of the enormous youth power in the country, have to realize that the situation of education in the country at all levels is dismally poor and, therefore, the youth power is rapidly becoming a burden rather than asset. To reverse this situation, before it gets to a point of no return, a drastic overhaul of the system is needed. This requires not only good policies but also competent policy-makers and administrators who can translate good policies effectively into productive realities. In biological systems, for a cell to differentiate into a specialized type to discharge its required functions in the body, it not only needs an external signal ('inducer') but the cell itself has to be 'competent' to respond. Accordingly, to bring about a positive change in academic institutions we not only need rules and guidelines as 'inducer', but the faculty and institutions also need to be prepared to be appropriately competent so that their response is in positive direction. The present system of appointments, starting from those of Vice-Chancellors and Principals to faculty recruitments and promotions is, unfortunately, working against the 'competence' and, therefore, would continue to promote predatory journals/conferences and the like. The learned bodies and Academies in the country need to come forward to effectively reverse the present trends so that the country's youth can realize and finally attain their potential.

Lakhotia S C (2015) Predatory journals and academic pollution Current Science 108 1407-1408

Lakhotia S C (2017) The fraud of open access publishing Proc Indian Natl Sci Acad 83 33-36. 